Nadwa : Jurnal Pendidikan Islam

Vol. 12, Nomor 2 Tahun 2018

Accredited by Ristekdikti based on Decree No. 51/E/KPT/2017

\title{
Analysis Study of Parental Choice of Education in The Millenial Era
}

\author{
Ahmad Fauzi \\ Institut Agama Islam Zainul Hasan Genggong Probolinggo \\ fauzi_nov4@yahoo.co.id \\ Rosyadi BR \\ IAIN Jember Jawa Timur \\ rosydibadar123@gmail.com

\section{Hasan Baharun} \\ Universitas Nurul Jadid Paiton Probolinggo \\ ha54nbaharun@gmail.com
}

\begin{abstract}
This article discusses parents' choices about the model of Islamic education in the millennial era. This study uses the library method. The results showed that parents had several criteria in determining the choice of educational models in the millennial era, namely a). schools that provide a lot of religious material b). combining religion and science, c). giving reinforcement to monotheism, d). madrasas that have vision, mission with good management. E). madrasas that have the same status as public schools.

Keywords: Millenial era; Madrasah; Parent's Choice; Islamic Education

Abstrak

Artikel ini membahas pilihan orang tua tentang model pendidikan Islam di era milenial. Penelitian ini menggunakan metode kepustakaan. Hasil penelitian menunjukkan bahwa orangtua memiliki beberapa kriteria dalam menentukan pilihan model pendidikan di era millennial yaitu a). sekolah yang banyak memberikan materi agama b). mengkombinasikan agama dan sains, c). memberikan penguatan pada tauhid, d). madrasah yang memiliki visi, misi dengan pengelolaan manajemen yang baik. E). madrasah yang memiliki status yang sama dengan sekolah umum
\end{abstract}

Kata Kunci: Era Millenial; Madrasah; Pilihan Orangtua; Pendidikan Islam 


\section{Introduction}

Historically, the madrasa education system for the first time began in the reign of Nizam al-Mulk in Baghdad, namely in 459 $\mathrm{AH}$ and continues to experience its development1, according to the needs of today's society. At the point of view the emergence, that the existence of madrassas is motivated by theological, economic and even political motivation, because at that time madrasa Islamic education institutions, was an educational typology in the form of formalization carried out by the government on pre-existing informal education, in addition to the government's involvement in management of madrasah education. Thus, the implementation of madrasas is understood as an educational model that is expected to contribute greatly to social reality in the midst of society2. Whereas the presence of madrassas in Indonesia, first started around the twentieth century, although in some information it was stated starting around the XI and XII centuries3.

The dynamics of madrasa education seek to bridge the relationship between pesantren education and modern education. Therefore, through a long struggle, madrasa education has gained its status to date, beginning with the issuance of the 1975 decree which states that the position of madrasas is the same and equal to other formal education. The policy was further strengthened by the birth of the Law on National Education System Number 2 of 1989, that madrasah education is a public school characterized by Islamic religion, the fact above is no longer a dichotomy, because both have the same status, even though the existence of madrasa

1 Ahmad Syalabi, Sejarah Pendidikan Islam, (Jakarta: Bulan Bintang, 1997), h. 90

2 Maksum, Madrasah ; Sejarah dan Perkembangannya, (Jakarta; logos, 1999), h. 110

3 Simanjuntak, Perkembangan pendidikan di Indonesia, (Jakarta; Departemen Pendidikan dan Kebudayaan, 1972), h. 19 
education in the last few years in the midst of society is still seen as second-class Islamic education. Therefore, madrasah education is generally only in demand by students whose intelligence and economic abilities are relatively low or mediocre4.

This view can be caused universally by several things, including; a) madrasah management system and work ethic, b) quality of human resources, c) inadequate facilities and prejudices, d) education as is, quality of low education, low innovation, and lack of interest. Such is the portrait of the life of madrasa education in the past few years of the previous year, but in its development it turned out that madrasa education was able to compete with other educational institutions or public schools.5 Even the portraits of madrasa education since 2011 to date have experienced significant development, this is marked by the number of Islamic education institutions, such as; MI, MTs, MA and PTKIN / PTKIS which have become the primary choice of the community (parental choice of education) to choose Islamic education in question. This view is socially reversed by several aspects including; Madrasah education is believed to be able to become a fortress of morality formation from all educational systems in the midst of today's society, besides that madrasah education is also perceived to generate scientific integration in Islam, as well as a form of investment, both capital and human (human capital investment) in order to improve the skills and knowledge for their students6.

Such is the portrait of madrasah education, since several decades in the past years continue to experience development in

4 Malik Fadjar, Madrasah dan Tantangan Modernitas, (Bandung: Mizan, 1998), h. 12

5 Jawa Post, 23 Juni 1994.

6 Malik Fadjar, Tantangan dan peran umat Islam dalam menyonsong abad XXI, (Surabaya, Makalah IAIN Sunan Ampel, 1995), h. 67 
accordance with the demands of society (social demand) today, as some research results explain, madrasah education model is no longer a second class (marginal), even perceived to be able to compete with educational institutions other general7.Therefore, this discussion is an important part to be discussed and carried out an analysis in this paper, as well as to describe, interpret the community's perception of the selection of madrasah education (parental choice of education), thus the madrasa education model has now become the first and first choice in the middle middle of community lifes.

\section{Paradigm of Madrasah Education and Social Dynamics}

Sociologically, the existence of Islamic education madrasah-as it is today, is a result of the construction of thought about the model of Islamic education in Indonesia between the pesantren education system and modern education, as it was founded by Abdullah Ahmed with his Adabiyah Madrasah in Padang Panjang in 1907 , which until now still plays its role and contributes to society9. Therefore, if examined in the context of history, the existence of madrasa education is an accumulation of various cultures (education of local wisdom) and educational traditions that develop in Indonesia, namely starting from prehistory or original traditions

In historical studies, before the formation of the madrasa education system, the teaching process was initially carried out in mosques and Islamic boarding schools, while the pesantren model education actually adopted an educational model developed by

7 Azyumardi Azra, Pendidikan Islam Tradisi dan Modernisasi Menuju Millenium Baru, (Jakarta: Logos, 2000), 57.

8 Hasan Baharun, "Manajemen Kinerja Dalam Meningkatkan Competitive Advantage Pada Lembaga Pendidikan Islam," At-Tajdid: Jurnal Ilmu Tarbiyah 5, no. 2 (2016): 243-62.

9 Azra, Azyumardi, Pendidikan Islam; Tradisi dan Modernisasi Menuju Millenium Baru, (Jakarta, Logos, 1999), 56 
the Hindu-Buddhist religion, namely by adopting its pre-existing religious education culture by giving the name of the pesantren which still connotes with religion is to give an impression to the community of the harmony between the Islamic religion they have just received with the religion that existed before. In the above context, they are expected to be interested in entering pesantren education by studying Islamic teachings. That was the case, in the perspective of Malik Fadjar better known as cultural grafting with the aim that pesantren institutions could be adaptive to the education that had existed before, so that the teachings of Islam conveyed were still mystical.10.

Therefore, after the open and stronger process of forming intellectual networks (intellectual webs) among Muslims with Haramain as the original source, the mystical nuances in Islamic boarding schools slowly began to diminish and move towards orthodoxy. At another level, after the process of changes in the content of learning and the existence of global provisions with the Islamic center in Haramain, it is possible for Islamic education actors to see a more programmed learning system, then developing learning content that can be managed with the system (Madrasi), as was the case- it was founded by Prime Minister Nidzamul Mulk, with the Nidzamiyah madrasa in Baghdad. Then this madrasa system can develop several Islamic regions. Departing from this context, it can be seen that the existing madrasa education in Indonesia is not an individual (indigenous) in the map of education in Indonesia, as well as the word madrasa which comes from Arabic, literally this word is equivalent to the meaning of school.

Whereas from the aspects of management and leadership, this madrasah education system has allowed for classical

10 Mastuhu, Memberdayakan Sistem Pendidikan Islam, (Ciputat, Jakarta: Logis, 1999), h. 45 
learning 11 , and this is different from the way developed in Islamic boarding schools. Management of Islamic education -Islamic schools- also allows for grouping in the process of learning activities, regarding how to convey to Islamic knowledge, which can then be done on a multilevel basis. The grouping, as well as to take into account the required time span, so that technically madrasa education seeks to be able to organize these activities, with a tiered system. Thus the portrait of madrasah education, increasingly has an orientation along with the dynamics of development. Therefore, efforts to improve the quality of Islamic education -Islamic schools- are continuously carried out, these views are shared responsibility, between the Ministry of Religion and National Education, the government and the general public12

In subsequent developments, namely since the last three decades, madrasa education has experienced polarization along with the demands of the times and people's expectations. Various policies have been carried out by the government to develop madrasa education, for example the enactment of the Special Program Aliyah Madrasah (MAPK) in 1987 which was later changed to the Religious Madrasah Aliyah (MAK) in 1994. Even in the same year, 1994 was also established and issued a madrasah curriculum which as a standardized curriculum in madrasas with several changes along with the development of science and technology. This view, it is expected that madrasah education can improve the quality of its graduates as well as the equivalent of public schools in general. Therefore, Islamic education - Islamic schools - has developed with various educational models, among

11 Ahmad Fauzi, "Organizational Culture of Islamic Public Education Management a Discurtive," dalam International Conference On Islamic Education (ICIED) Innovations, Approaches, Challenges, And The Future (Malang: Fakultas Ilmu Tarbiyah dan Keguruan UIN Maulana Malik Ibrahim Malang, 2017), 130-36.

12 Hasbullah, Sejarah Pendidikan Islam di Indonesia, Lintasan Sejarah Pertumbuhan dan Perkembangan, (Jakarta: Grafindo Persada, 1996), h. 70 
others; MTs / MTsN and MA / MAN with Featured programs, Information Technology-based education programs and Language Programs. Not to mention Islamic Religious Higher Education, such as PTKIN; UIN, IAIN, STAIN with various departments and study programs, not to mention Private Islamic Religious Higher Education (PTKIS) which is under the auspices of Kopertais.

Thus, the dynamics of portraits of madrasa education in milineal era become the basis for people to choose the model of Islamic education in accordance with various views. Namely; a) public perception of madrasah become public schools plus religion b) the madrasah education system able to integrate religion with the public, c) people's views on Islamic education madrasah- more are built based on theological reasons, d) the madrasah education system already has good vision and mission and managed with good management. e) the role of madrasah has same authority with National Education System13

\section{Challenges and Problems in Madrasah Education}

As a Islamic education institution -madrasah- has its own characteristics in the process of implementing Islamic education, namely as the formation of morality and personality for students, as well as being a controller of Islamic education that is oriented to (tend to religious and moral values). Therefore, the presence of the madrasa education system is expected to have two abilities at the same time, namely mastery and depth in the field of general knowledge and religion accompanied by values (spirituality) as a value system and become core values, core beliefs of the development of madrasah education. Thus the portrait of future madrasa education has prospects that are considered quite good,

13 H.A.R Tilaar, Paradigma Baru Pendidikan Nasional, (Jakarta: Rineka Cipta, 2000), h. 32 
although there are still a number of madrassas in some parts of the country, still facing various problems, for example; inadequate quality of human resources and educational facilities, and unprofessional management systems, not to mention the relatively small number of students. Therefore, looking at the social challenges referred to, Malik Fadjar explained that, the problem basically originated from the internal conditions of madrasa education, regarding the inability to balance the needs of society towards the higher quality of education each year.

Thus, some of the problems in madrasah education are meant to be a challenge for the implementation of Islamic education. Therefore, with the changes and challenges of the flow of globalization, inevitably it forces Islamic education to make changes in a better direction, so that it can overcome global developments and be able to meet the needs of society (social demand). Sociologically, the effort to face the challenges referred to, in Mastuhu's perspective can be done by finding a model of Islamic education -madrasah- which is in accordance with the challenges of his time and must be done (aproactiveanticipatory), by preceding the development of problems that will be present in the future. It is not (reactive and defensive), that is, answering, defending the truth after a challenge, as the birth of the SKB of three ministers which establishes the status and position of madrasas is the same as other public schools 14 .

Therefore, to deal with the various challenges and problems above, a fundamental reform is needed which includes; renewal of the management system and work ethic of the madrasah, improvement of the quality and quantity of the teacher, reorientation of the curriculum and physical improvement and facilities. In the field of management, so far it appears that most

14 Mastuhu, Dinamika Sistem Pendidikan Pesantren, (Jakarta: INIS, 1994), h. 79 
of them have not been able to be managed with good managerial, from the aspect of their teachers, most of them are still less professional, while the quality of madrasah education is still relatively low. Departing from this view, can be a direction and purpose in building a portrait of Islamic education -madrasahthe future.

Historically, portraits of madrasa education have strong cultural roots, by making religious values as social capital (social capital) and even become habitus in the dynamics of future madrasa education, this view, as explained by John Naisbitt and Patricia, a leading futurlog on fig in the 90 s, which predicted that the 21 st century was a new era, which was marked by the rise of religious values (spirituality), it turned out that the prophecy became an undeniable truth, that the changes taking place in society made religion the basis of life guidelines human. Thus the internalization of these values, becoming (social capital) for the process of administering Islamic education - madrasah- and this view certainly makes the madrasah education model increasingly in demand amid the social conditions of today's society.

\section{Reorientation of Madrasah Education in Responding to Social Change}

Madrasah education development must be carried out thoroughly. Therefore, these efforts must pay attention to all elements in the madrasah education system both in the form of elements (organic), which become an important part, namely; a) the role and actions of a leader, b) the role and duties of an educator, b) the role of the community and the involvement of stakeholders and, c) students and parents 15. While elements (inorganic) include several things; the purpose of madrasa

15 Muhaimin, Eksistensi Madrasah sebagai sekolah Umum yang berciri khas Islam, (Tarbiyah, IAIN Malang, no. 45 tahun xiv Januari-Maret, 1997), h. 90 


\section{$320 \mid$ Ahmad Fauzi, at.all}

education, the views and values of madrasah education, curriculum structure according to community needs, learning process activities, management and development of madrasa education. These various efforts are needed, an in-depth and critical study of contemporary (historicity) and some possibilities that will come. Anthropogically, the above study is expected to obtain data on the management system of madrasah education in the past as a material for the evaluation of the existence of madrasas at present, both in terms of management systems, evaluation, in the management process, so as to conduct comparative studies related to issues global and contemporary issues in the field of managing madrasah education, namely as a conceptual framework and the basis for the development of future madrasah education.

At another level, the development of Islamic education Islamic schools-is not a simple job. Because of this development, it requires a good managerial system through the planning process in accordance with the vision, mission and goals of madrasah education. The above planning is intended to help focus on targets, allocations, and continuity, as well as a process of thinking to determine matters relating to the needs of the community towards current madrasa education. By means of determining what you want to achieve, why is it done, how is the process of achieving it, who is able to do it, and when can the plan be implemented16. In addition, the efforts made by madrassas in the framework of developing the education system in question, can also be done through two approaches, namely; macro review (macroscopic) and micro-microscopy. Departing from the two approaches above, an analysis can be made of the current madrasa education system and linking it to a broader social reality, both

16 Steenbrink, Pesantren, Madrasah, Sekolah, (Jakarta: LP3ES, Cet-2, 1984), h. 65 
sociologically, economically and politically. While the second model can be done by connecting madrasa education in one unit and interacting with one another.

Thus the two approaches to the above models complement each other, especially amidst the increasingly open social reality of society, through interactions from various aspects of social life. Therefore, an attitude of openness and courage is needed in solving the above problems in several ways, namely; a) clarity between the aspirations of the operational steps, $b$ ) empowerment of existing institutions by restructuring the system, c) improvement, renewal, and development in the management system or management of madrasah education, d) improvement of human resources needed. Such steps are expected to play a more articulate role in the future. Therefore, a deep thought is needed in looking at the above problem, to eliminate the impression that conceptual thinking in the development of Islamic education is idealistic, romantic or even less realistic. The implementation sometimes experiences some obstacles and difficulties, even the intensity of the implementation is still questionable. Observing these conditions, a paradigm is needed for the development and orientation and steps of its development, through the paradigm of formism, the mechanism of paradigm, and the paradigm of organism 17 .

The paradigm of formism comes from a dikhotomic perspective on reality in social life, and everything is seen from two opposing sides. This view has implications for the implementation of Islamic education in its development, thus giving birth to dualism in education, namely religious education and general education. While the mechanism of the paradigm, is a perspective on social life which consists of several aspects. In

17 Muhaimin, Eksistensi Madrasah Sebagai Sekolah Umum yang Berciri Khas Islam, (Tarbiyah, IAIN Malang, no. 45 tahun xiv Januari-Maret, 1997), h. 23 
this context, education is seen as the cultivation and development of a set of values of life, each of which moves and runs according to their respective functions between one element to another, whether they can consult or not. This kind of paradigm seems to be developed in public schools or colleges which are not characterized by Islam, where religious studies are only given two hours and two credits a week, even as a general basic course. Therefore, as an implication, the development of Islamic education depends on the ability and (political will) of these leaders, especially in building cooperative relationships with other subjects, whether horizontal and independent or not consulted lateral-sequential. While the paradigm (organism), is a paradigm that departs from a general view, where Islamic education is a unity as a system for the delivery of Islamic education which consists of several other components. In this context, the organism paradigm makes religious values the core values of the implementation of Islamic education, namely as a source of consultation on the implementation of education, even from the three paradigms, organisms that are considered the most ideal and to this day continue to be developed.

In another context, efforts to develop Islamic education according to Dawam Raharjo must be able to accommodate three interests, namely; 1) as a vehicle for fostering individuals in carrying out Islamic practices 2) clarifying and strengthening the existence of Islamic education -madrasah- with the school system, as a vehicle for fostering intelligent, knowledgeable, personal citizens 3) able to respond to future demands, so gave birth to humans who have readiness to enter the era of globalization, industrialization and the information age. Therefore, to integrate the three things above, the development of madrasas requires a reorientation that covers all aspects related to madrasah education in the form of organic and inorganic elements. Thus the reorientation will bring up a variety of 
problems that must be answered first as a paradigm of developing Islamic education (good schools) both related to madrasah education goals, direction of development, education system18, curriculum development. Therefore, several things that need to be understood first are the conception of the nature of humanity19, the conception of the purpose of Islamic education and science in

Islam by way of addressing the epistemological and methodological problems.20

Departing from a number of steps to address the development of madrasah education above, Mastuhu practically provides the concept of a development model that must be the basis of the development referred to include: a) the basis of Islamic education based on theocentric and anthropocentric as part of the theocentric concept, this view is certainly different from secular education which is only anthropocentric, b) the purpose of education, in building the worldly life through education as a manifestation of his devotion c) the concept of human nature that must be developed in a sustainable manner so that it produces positive values, and d) the values of struggle in developing Islamic education and solely is devotion to Him.

\section{Community Perception of Madrasah Education}

In social reality, education is an important part that cannot be separated from society. Therefore, education and society have a very strong dialogical and reciprocal relationship, so this reciprocal relationship can be explained through philosophical, sociological and paedagogies studies. Philosophically, that

18 Abdur Rahman saleh, Educational Theory a Qur'anic outlook, (Makkah Mukarromah; Umm al-Qura' University, 1984), h. 45

19 Ahmad Tafsir, Ilmu Pendidikan dalam Perspektif Islam, (Bandung, Remaja Roesdakarya, Cet-2, 1994), h. 90

20 Amin Abdullah, dalam Religiusitas Iptek, (Fak.Tarbiyah Suka dan Pustaka Pelajar, Yogyakarta, 1998), h. 54 


\section{4 | Ahmad Fauzi, at.all}

modern social reality of society is a typology of advanced educated society21. Thus, the advanced Islamic education model madrasah- can only be found in the midst of the social reality of advanced society, both socially, culturally and intellectually. The pagan, gives an illustration, that if the madrasah education is passive and conservative, then the society that is produced will be less productive and creative. Philosophical education is also a vehicle for inheritance and the development of social and even moral values. Whereas sociologically, Emile Durkheim explained that the transformation of education is the result and symptom of social transformation, which can only be explained through a study of ongoing social transformation. Durkheim gave the example that the transformation and attainment of education in the sixteenth century must be explained through social movements that are oriented back to the classic spirit as a reaction to the gloom of the ideals of the middle ages22.

Thus the portrait of Islamic education - Islamic schools - in the midst of the people in Indonesia, as Zamasyari Dlofier said that the process of Islamic education in pesantren basically describes an attempt of certain Islamic community groups in Java to maintain and maintain traditional Islamic ideology for the sake of upright and solidarity of the Muslim community (ahlussunnah wal-jamaah)23. Likewise with madrasah education at this time, in the community's perception that the main choice (parental choice of education) to send their children to school is inseparable from the value system built by Islamic education-madrasah-in addition to preserving the value system, because of the portrait of religious education (spiritual) becomes an important part of the condition

21 Noor Syam, Filsafat Pendidikan dan Dasar Pendidikan Pancasila, (Surabaya; Usaha Nasional, 1986), h. 117

22 H.A.R Tilaar, Beberapa Agenda Reformasi Pendidikan Nasional, (Magelang; Indonesia Tera, 1999), h. 34

23 Zamakhsari Dhofier, Tradisi Pesantren Studi Tentang Pandangan Hidup Kiai, (Jakarta: LP3ES, 1994), h. 26 
of society today, as some of the results of research, such as Hendricks, Ludeman in Tjahjono, which states that religious values (spirituality) in various aspects become a major part of influencing individual social actions, including inside building Islamic education leadership is even seen to inspire driving individual behavior 24. In fact, Tobroni in his research results stated that, issues (spirituality) in various fields including their leadership portraits were increasingly accepted since the $21 \mathrm{st}$ century, such as Aburdene and Fukuyama which mentioned the value century of the value age 25 . Likewise, the portrait of madrasah education is increasingly in demand in the midst of society today, so Islamic education -madrasah- is no longer the second class, and is not only attractive to the lower midle class but also social class. middle to upper, (upper-midle class).

Based on this view, it can be understood that the Islamic education system is a strategic part of the position allocation mechanism, which finds that the school system has a mandate from the community to be able to channel its members into certain positions26. Because sociologically, education has an important role in positioning individuals in certain social classes, so too social stratification has an important role in the education system, including in choosing an educational model, namely to place students at certain classes, such as; education models, schools or

24 Gay Hendricks dan Kate Ludeman, The Corporate Mystic: Guidebook for Visionarities with Their Feet on the Ground. (New York: Bantam Books. 1996), h. 89.

25 Tobroni, Perilaku Kepemimpinan Spiritual dalam Pengembangan Organisasi pendidikan dan Pembelajaran; Kasus Lima Pemimpin Kota Ngalam (Jogyakarta, Disertasi tidak diterbitkan, PPs UIN Sunan Kalijaga, 2005), h. 12.

26 Ahmad Syalabi, History of Muslim Education, (Beirut: Dar Alkasysyaf, 1987), h. 89. 
madrasas as desired by the community and can significantly influence graduates 27

That is the interrelation relationship which shows the significant influence between elements in the social system. Social stratification has a role that influences the process of administering education, then education itself has a role and influence on social stratification of society. Therefore, basically, education and the community stratification system have an integral and dialogical relationship between one another. This view shows that there is a significant relationship and influence that the lower a person's social class will affect the low learning achievement, whereas the higher a person's social class will affect the level of student achievement28, although in some cases it is also unjustifiable, because one's achievements do not provide space for social classes, but when it comes to parents' choice of education for their children, social stratification can be justified in some ways, as a result Marno's research, in terms of the perspective of the upper middle class society on the selection of an education system for their children, explained that an advanced education model, also having high trust from the community, could only be in demand by some of the upper classes. Because of that, the organizers of education both schools and madrasas continuously to develop (innovate) their education

Therefore, theoritical view of the public on the choice of education both in schools and in Islamic education institutions general schools- can be based on several considerations, including: a) differences in the quality of education, b) differences in access to education facilities according to individual social class status, c) differences in motivation, values, individual

27 Margaret Preedy, Managing the effective School, (London: Paul Chapmant Publising, Liverpool, 1993), h. 65

28 Jeanne H.Ballantine, Sociology of education, a systematic analysis, (Wright State University, Prentice Hall Englewood Cliffs), h. 78 
attitudes, differences in will, ideals and desires of parents. Thus the portrait of education development is an important part to be done to foster a system of values for the current educational model, as has been done by several madrasas, and has implications for the way people view madrasah education today, and no longer consider second-class education, and Islamic education -madrasah- is currently the first and foremost educational choice of all existing education, because education is considered to have been able to integrate religion and general knowledge.

\section{Conclusion}

Madrasah faced various problems both regarding the quality of human resources. Efforts to change the negative cycle to be positive or change schools that are not qualified to be good ( good school) certainly require an approach and strategy for the development of Islamic education in question. Thus, this development is continuously carried out, so that the existence of madrasa education today is no longer the second class, where the perception of society today has put Madrasah education as the main choice (parental choice of education), as some research results in the past few decades significantly shows, the enthusiasm of the community towards madrasa education, besides that the public perception of the portrait of madrasah education is based on several theological reasons, namely; Madrasah education is believed to be a bastion of morality (spirituality) of all educational systems, as well as a form of planting Islamic values and intellectual formation.

The public's view of Islamic education -madrasah- has experienced a shift towards a more positive direction from the previous view of society which considers that madrasah 
education as a second class education institution and only for lower midle clas even only is understood as a model education that teaches religion. But education above madrasas, has become a much sought after educational model as well as a favorite choice of the community (parental choice of education) both the lower midle clas and upper-midle classes today. portraits of madrasa education in milenial era become the basis for parent to choose the model of Islamic education in accordance with various views. Namely; a) public perception of madrasah become public schools plus religion $b$ ) the madrasah education system able to integrate religion with the sain, c) people's views on Islamic education built based on theological reasons, d) the madrasah education system already has good vision and mission and managed with good management. e) the role of madrasah has same authority with other school in general.

\section{References}

Abdullah, Amin, dalam Religiusitas Iptek, Fak.Tarbiyah Suka dan Pustaka Pelajar, Yogyakarta, 1998.

Azra, Azyumardi, Pendidikan Islam Tradisi dan Modernisasi Menuju Millenium Baru, Jakarta: Logos, 2000.

Azra, Azyumardi, Pendidikan Islam; Tradisi dan Modernisasi Menuju Millenium Baru, Jakarta, Logos, 1999.

Baharun,Hasan, "Manajemen Kinerja Dalam Meningkatkan Competitive Advantage Pada Lembaga Pendidikan Islam," At-Tajdid: Jurnal Ilmu Tarbiyah 5, no. 2 (2016): 243-62.

Ballantine, Jeanne H. Sociology of education, a systematic analysis, Wright State University, Prentice Hall Englewood Cliffs.

Dhofier, Zamakhsari, Tradisi Pesantren Studi Tentang Pandangan Hidup Kiai,(Jakarta: LP3ES, 1994.

Fadjar, Malik, Madrasah dan Tantangan Modernitas, Bandung: Mizan, 1998. 
Fadjar, Malik, Tantangan dan peran umat Islam dalam menyonsong abad XXI, Surabaya, Makalah IAIN Sunan Ampel, 1995.

Fauzi,Ahmad, "Organizational Culture of Islamic Public Education Management a Discurtive," dalam International Conference On Islamic Education (ICIED) Innovations, Approaches, Challenges, And The Future (Malang: Fakultas Ilmu Tarbiyah dan Keguruan UIN Maulana Malik Ibrahim Malang, 2017), 130-36.

Hasbullah, Sejarah Pendidikan Islam di Indonesia, Lintasan Sejarah Pertumbuhan dan Perkembangan, Jakarta: Grafindo Persada, 1996), h. 70

Hendricks, Gay dan Kate Ludeman, The Corporate Mystic: Guidebook for Visionarities with Their Feet on the Ground. New York: Bantam Books. 1996.

Jawa Post, 23 Juni 1994.

Maksum, Madrasah ; Sejarah dan Perkembangannya, Jakarta; logos, 1999.

Mastuhu, Dinamika Sistem Pendidikan Pesantren, Jakarta: INIS, 1994.

Mastuhu, Memberdayakan Sistem Pendidikan Islam, Ciputat, Jakarta: Logis, 1999), h. 45

Muhaimin, Eksistensi Madrasah sebagai sekolah Umum yang berciri khas Islam, Tarbiyah, IAIN Malang, no. 45 tahun xiv Januari-Maret, 1997.

Muhaimin, Eksistensi Madrasah Sebagai Sekolah Umum yang Berciri Khas Islam, Tarbiyah, IAIN Malang, no. 45 tahun xiv Januari-Maret, 1997.

Preedy, Margaret, Managing the effective School, London: Paul Chapmant Publising, Liverpool, 1993.

Saleh, Abdur Rahman, Educational Theory a Qur'anic outlook, Makkah Mukarromah; Umm al-Qura' University, 1984.

Simanjuntak, Perkembangan pendidikan di Indonesia, Jakarta; Departemen Pendidikan dan Kebudayaan, 1972

Steenbrink, Pesantren, Madrasah, Sekolah, Jakarta: LP3ES, Cet2, 1984.

Syalabi, Ahmad, History of Muslim Education, Beirut: Dar Alkasysyaf, 1987. 
Syalabi, Ahmad, Sejarah Pendidikan Islam, Jakarta: Bulan Bintang, 1997.

Syam, Noor, Filsafat Pendidikan dan Dasar Pendidikan Pancasila, (Surabaya; Usaha Nasional, 1986.

Tafsir, Ahmad, Ilmu Pendidikan dalam Perspektif Islam, Bandung, Remaja Roesdakarya, Cet-2, 1994.

Tilaar, H.A.R, Beberapa Agenda Reformasi Pendidikan Nasional, Magelang; Indonesia Tera, 1999.

Tilaar, H.A.R, Paradigma Baru Pendidikan Nasional, Jakarta: Rineka Cipta, 2000.

Tobroni, Perilaku Kepemimpinan Spiritual dalam Pengembangan Organisasi pendidikan dan Pembelajaran; Kasus Lima Pemimpin Kota Ngalam, Jogyakarta, Disertasi tidak diterbitkan, PPs UIN Sunan Kalijaga, 2005. 